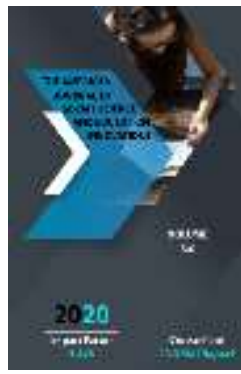

\title{
Humanity And Divinity In The Interpretation Of Eastern Philosophy
}

\author{
Jumaniyozova Dilfuza Kamalovna \\ Doctor Of Philosophy (PhD), National Institute Of Fine Arts And Design Named After \\ Kamoliddin Bekhzod, Assistant Professor The Department Of Social Sciences, Pedagogy And \\ Vocational Education, Uzbekistan
}

\begin{abstract}
Journal Website: http://usajournalshub.c om/index,php/tajssei

Copyright: Original content from this work may be used under the terms of the creative commons attributes 4.0 licence.
\end{abstract}

\section{ABSTRACT}

The article examines the issue of humanity and divinity in Eastern philosophy. The views of Eastern and Western scholars in this regard are at this point comparable in terms of philosophy, all branches of science, in terms of theology.

\section{KEYWORDS}

East, philosophy, humanity, divinity, theology, space, mentality, civilization, Islam, Taoism.

\section{INTRODUCTION}

It has been noted since ancient times that the East is a historical and cultural entity that differs from Europe in its unique geographical location, country, traditions, views and way of life, although its scientific study began in the New Age. Geographical discoveries, especially the discoveries of India and China by Europeans, show that human development, the formation of civilizations were different, as the famous historianphilosopher A.J. Toynbee said, "local origin in the dimension of space" [3. 44-45]. The local formation of civilizations does not prevent us from looking at the East as a whole, a region, a conglomerate with its own historical and cultural paradigm. European scientific and technological progress has not only brought East and West closer together, but has also led to the differentiation of the civilizations that have emerged in their bosom, to the local development as a "natural historical and cultural reality" [2. 91-93]. 
Some researchers, such as S. Huntington, even believe that these differences led to a "clash of cultures" [5. 7-12]. Thus, it has become a tradition today to look at the East as a whole, as a conglomerate, and in many studies, Eastern morality, etiquette, culture, mentality are seen as a reality, a historical and cultural paradigm. However, it must be acknowledged that different historical and cultural paradigms, mentality, lifestyle, epistemological experiences have been formed within the East. A.J. Toynbee in his book "Understanding History" notes that more than a dozen civilizations have emerged, developed and declined in the East itself [4. 94]. Along with civilizations, social changes took place in their own "mimesisoriented" direction [4. 95], on the basis of which not only moral and spiritual views, norms, but also religions emerged, one belief was replaced by another. For example, the Pestorian and Monophysite sects of Christianity originated in the Urfa region of Mesopotamia, the Shia sect of Islam in northern Arabia, the Mahayana sect of Buddhism in the Ox-Yaksart latitude, and early Buddhism on the banks of the Middle Ganges [2. 41]. There are many such examples. But our task is not to study the genesis of religion and religious movements, this topic is widely covered in special textbooks and manuals, reference books, but also to study the interpretations of issues of humanity and divinity in Eastern philosophy. We therefore believe that these issues can be studied from the perspective of TaoConfucianism, Indo-Buddhism, and Islamicmysticism, which have transformed Eastern philosophy into a unique epistemological doctrine, worldview, and way of life. It is the study of these religious-philosophical schools, the concepts of the problem in them, that helps to shed more light on the subject.

\section{METHODOLOGY}

Dao-Confucianism is a religious-philosophical and socio-moral doctrine that originated in ancient China in the 7th-6th centuries. Its founder was the Chinese thinker Lao Tzu, who lived in the 7th-6th centuries. "Dao means a way. As long as a person lives, he is always on the road. But the true way is the way in which man finds the Creator". [5. 13] As the Indian philosopher Bhagavan Sri Rajnish noted, "The Tao respects individuality, not sociality; The Tao respects uniqueness, not gangs. There is no tradition in Dao. The Tao is rebellion, the greatest rebellion of all available possibilities". [7. 13] But this "rebellion is aimed at understanding the human person, his unique qualities and powers. All are equal before the Dao. All inequality in society is due to ignorance". [7. 316] The philosophy of the Tao is described in the treatise Dao-de Jing (4th-3rd centuries). It states, "Even the Great Heaven will follow the Tao. To understand the Dao, to follow it, to join it is the purpose and happiness of the purpose of life". [8. 41] The Tao is drastically different from the religious-philosophical currents in the East; if Confucianism, Buddhism, and Islam promote communist ideas and advocate the service of social interests and desires, Taoism emphasizes individuality, the free thinking of the individual, the free living. He advocates living alone, ahad. That is why L.S. Vasilev considers Taoism and Taoism in the East as a trend that encourages secularism, passion, curiosity, in short, to give up what connects it with the world. [9. 310-311].

The Tao is drastically different from the religious-philosophical currents in the East; if Confucianism, Buddhism, and Islam promote communist ideas and advocate the service of social interests and desires, Taoism emphasizes individuality, the free thinking of the individual, the free living. He advocates living alone, ahad. That is why L.S. Vasilev considers Taoism and Taoism in the East as a trend that encourages secularism, passion, curiosity, in short, to give up what connects it with the world. [9. 310-311].

Taoism sees man and his duty to find the Dao, to reach Him. All human qualities are focused 
on understanding Dao. Doctor of Philosophy V. Alimasov writes, "In Taoist philosophy there is the first substance, but there is no god, there are gods, but there is no dogma. The godliness in the Tao is in believing in the Integrity of life, of being. No one created the universe or man, and if someone created them, there is a reason to create them". [1. 42-48].

The absence of God is not yet a denial of the existence of the divine. In Taoism, the Dao is divine. The point here is not in the name, not in the word, but in the essence. The Tao is the Whole, the One, the Inevitable. [9.42-48] The Dao is "everywhere, in everything, and in everything is above everything. Dominance is a sign of dominion, because it creates things if it wants to, does not create if it does not want to, and even destroys them". [1.48] This feature makes the Dao a total reality. There is also totality in divinity, otherwise it cannot affect the objective being. [6.26]

True, Taoism contains speculative thoughts, ideas, and approaches. It avoids the problems of real existence and succumbs to absolute subjectivism. However, it should not be forgotten that Taoism as the first religious and philosophical doctrine is still a primitive notion, an experience of philosophical and epistemological research of people in the period when the understanding of the role and functions of man in social existence is just beginning.

Confucius (Master Kun, 551-479) expressed the political and moral requirements of his time; he preferred rationality, not irrationality, to the needs of the state, not to an abstract god, and to life, not mysticism. [9. 28] Indeed, Lun Yu ("Conversations and Reflections"), which reflects the legacy of Confucius, does not contain such terms as "religion", "god", "god", "spirit", "beyond the world" the ideas aimed at raising it, living it in harmony, harmony and reconciliation with society and the state are paramount. However, Confucianism was gradually developed, and the followers of Master Day raised it to the level of the state religion. Therefore, without knowing Confucianism, it is impossible to fully understand both Chinese civilization and Eastern philosophy.

\section{RESULTS}

Although Confucius did not use the terms "god" or "god", he did refer to categories such as "Heaven" and "Great Heaven" Heaven, in his view, has divine power, authority, all events under heaven or on earth, things happen because of the command and will of the Great Heaven, people's lives and actions are at the disposal of Heaven. Hence, the relationship between humanity and divinity can be determined by the relationship between man and Heaven. So what does this relationship reflect?

First, Confucius understood that the will of Heaven is omnipotent. "Only Heaven is greater! He only imitated him!" [10. 68] It is true that some scholars interpret Heaven as the "Spirit of the Supreme Emperor" at this point. [10. 68] However, Confucius' later ideas about Heaven show that such an interpretation is narrow, even inaccurate. Second, man cannot be perfect and mature on his own, but he can only be noble and perfect, supported by Heaven, following the path of Heaven (Dao), and obeying the command of Heaven. [11. 156]

Third, the concept of "li" put forward by Confucius - "Management of society, customs and order of things" - is essentially living in accordance with the rules, norms and procedures established by Heaven. The concept of "Lee", - says F.Musaev, Doctor of Philosophy, - includes the systems of HeavenEarth-Man, monarch-nobles-people, government-humanity-justice. Each system has upper, middle and lower parts. Their harmony with each other creates the possibility of targeted management of the state and society. Heaven, monarch, and government are the highest of these parts. 
That is why the rest will obey and serve them". [12.17]

Apparently, Confucius deified Heaven, viewing everything as the result of His will. Hence, Confucius acknowledged that the will of Heaven was a divine power. This idealistic interpretation of the thinker, that is, the elevation of the will of Heaven to the level of transcendence, was fully realized by his followers, especially the philosophers who shaped neo-Confucianism, and through their consistent efforts, Confucianism became the religious-philosophical and political-moral heritage of the Chinese people. [10. 332-333.] The deification of the will of heaven, its understanding at the level of absolute determinist reality, does not deny the role, will and will of man. The fact that Confucianism is also called "political philosophy" or "political-moral doctrine" indicates that it was dominated by problems of reality and social existence.

It is also recognized that a person's relationship with his family, society and state is governed by immanent laws. It is therefore wrong to seek to create a pure religious doctrine from Confucianism. It should not be forgotten that the glorification of man and humanity, the "noble land", the promotion of a virtuous, just king to the ideal level. These issues have been extensively covered in the literature published in recent years [13.22].

It is not possible to analyze them on this topic, to make an objective assessment of this or that approach. The growing interest in the historical and cultural heritage, especially in the philosophical and moral heritage of Western scholars, is a real phenomenon. Therefore, based on the fundamental works published in Europe and Russia in recent years, we can express the following views on the problem.

"Divinity prevails over some religions and sects, V. Alimasov wrote. Focusing on the theme of "humanity and divinity", it expresses the essence of the inner transcendence in religions. Divinity is not the teachings, lifestyles, theological imaginations of individuals, it is the quintessence of the essence on the basis of these views. Only then can divinity be One, Whole, One. Some religions, in some respects, have the character of humanity, universality in the divine shell of the sect". [1. 220] The divinity of a religion also does not help the transcendent to fully understand that he is connected with the whole of humanity, with the spiritual world, which is a universal reality. This is why experts focus on the search for universal aspects rather than specificity from the teachings of Confucius. So, religion is not a transcendent, god or Heaven, but a universal character, a unity of values that unites people. Philosophy, as a field of science, stems from this approach, it is not concerned with the existence or nonexistence of Heaven or God, but with the problems of the transcendent relation to man or man's relation to Heaven, God, the transcendent. It is at this point that philosophy, all fields of science, are different from theology.

\section{CONCLUSION}

The study of concepts and interpretations in Eastern and Western philosophy shows that there is no concept of religion, transcendent, outside of man. Religious-philosophical, doctrines prevail over divinity, while scientific-philosophical currents focus on humanity, humanism. [15. 9]

The question of which of them should be approved and which should be rejected has been going on for centuries, especially after the New Age. In our view, this question does not lead to a definite conclusion, but leads to scholastic interpretations. Therefore, the dualistic approach formed in philosophy, that is, taking an intermediate path, is expedient. It is as difficult to substantiate objectivity through irrational intuition as it is to find God, God, through reason, rationality. If religion 
and theology help the spirituality of the individual, the formation of socio-moral qualities in him, it is necessary to use the positive experiences in them.

"A philosopher asked Saint Anthony, who could neither read nor write, from which book did you get the truth you were preaching. Saint Anthony was silent, pointing to heaven with one hand and earth with the other" [16. 7]. By this he meant that the great truth is not in the absolute heavens, nor in the divine, nor in the absolute earth, nor in man, but in the harmony of the great truth. The same can be said of the harmony of humanity and divinity in the spiritual formation of the individual.

\section{REFERENCES}

1. Alimasov V. Philosophy or the art of thinking. - T.: Noshir, 2008.

2. Alimasov V. Confucianism and Eastern statehood. - T.: Philosophy and Law, 2006.

3. Toynbee A.J. Civilization before the judgment of history. Collection. - M.: Rolf, 2002.

4. Toynbee A.J. Comprehension of history. M.: Progress, 1991.

5. Huntington S. Collision of civilization. M.: AST, 2005.

6. Bhagavan Shri Rajneesh. Tao. A path without a path, vol. 1. - M.: 1994.

7. Mamadaliev Sh.O. People's power: theory and practice. - T.: IIV Akademiya, 2003.

8. Tao-Te Ching. - M.: EKSMO, 2006.

9. Vasilyeva L.S. History of the religions of the East. - M.: Vostoch. liter. 2004.

10. History of Chinese philosophy. - M.: Progress, 1989.

11. Ancient Chinese philosophy. Collection of texts in two volumes. T.I. - M.: Thought, 1972.

12. Musaev F. Philosophical and legal bases of building a democratic state governed by the rule of law. - T.: Uzbekistan, 2007.
13. Shutsky Yu.K. Chinese classic book of change. Yi Ching. - M.: Russian book. Creativity, 1993.

14. History of the ancient East. From early states to ancient empires. - M.: East Literature RAN, 2004.

15. Religion and Society. Reader on the sociology of religion. - M.: Aspect - press, 1996.

16. Saint Anthony. Instructive thoughts, good advice, chosen from the creations of men of the wise and saints. - Moscow: Publishing house. Donskoy Monastery, 1991. 